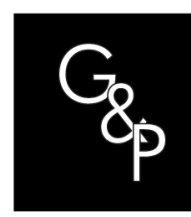

\title{
Influence of organizational culture on the environments of innovation and organizational performance
}

\author{
Influência da cultura organizacional sobre os ambientes de \\ inovação e desempenho organizacional
}

\author{
Klaus Siegmar Schuldt ${ }^{1}$, Giancarlo Gomes ${ }^{1}$ (1) \\ ${ }^{1}$ Universidade de Blumenau - FURB, Programa de Pós-graduação em Administração - PPGAd, Blumenau, SC, \\ Brasil.E-mail: klaus.schuldt17@gmail.com; giancarlog@furb.br
}

How to cite: Schuldt, K. S., \& Gomes, G. (2020). Influence of organizational culture on the environments of innovation and organizational performance. Gestão \& Produção, 27(3), e4571. https://doi.org/10.1590/0104-530X4571-20

\begin{abstract}
Innovation is an inherent and fundamental phenomenon for the prosperity of the textile industry. One of the factors that can stimulate the propensity for innovation is the organizational culture. This is due to the fact that by influencing employees' behavior, one can achieve that they accept innovation as a fundamental value in the organization and commit to it. Therefore, it is opportune to deepen the relationship between organizational culture and innovation and organizational performance. That way, the objective of this study was to analyze the influence of the organizational culture on the internal and external environment of innovation and organizational performance in an organization of the textile sector. The research was descriptive quantitative, transversal, with a sample of 186 respondents. The data were analyzed by means of Structural Equation Modeling. As a main result, the collaborators highlighted the Results dimensions; Processes and Internal relationship of the innovation group as present in the environment conducive to the development of innovations. The Organizational Culture of the company is congruent with the smallest distance of power and high collectivism. The theoretical model was adhered to in the textile organization studied, with respect to the influence of Organizational Culture on the internal and external Environment to the development of innovations contributing to the application of new studies. With this, it is possible to infer that there is a favorable influence of the organizational culture on the environment of development of innovations and organizational performance in the organization researched.
\end{abstract}

Keywords: Organizational culture; Innovation; Organizational performance.

Resumo: A inovação é um fenômeno inerente e fundamental para a prosperidade da indústria têxtil. Um dos fatores que podem estimular à propensão a inovação é a cultura organizacional. Isto se deve ao fato de que ao influenciar o comportamento dos funcionários, pode-se lograr que aceitem a inovação como um valor fundamental na organização e se comprometam com ela. Portanto, é oportuno aprofundar a relação entre cultura organizacional e inovação e desempenho organizacional. Assim, o objetivo deste estudo foi analisar a influência da cultura organizacional sobre o ambiente interno e externo de inovação e desempenho organizacional em uma organização do setor têxtil. A pesquisa foi quantitativa descritiva, transversal, com uma amostra de 186 respondentes. Os dados foram analisados por meio de modelagem de equações

Received Jan. 11, 2018 - Accepted Oct. 27, 2018

Financial support: None. 
estruturais. Como principal resultado, os colaboradores destacaram as dimensões Resultados; Processos e Relacionamento interno do grupo de inovação como presentes no ambiente propício ao desenvolvimento de inovações. A Cultura Organizacional da empresa é congruente com a menor distância do poder e alto coletivismo. O modelo teórico se apresentou aderente na organização têxtil estudada, no que tange a influência da Cultura Organizacional ao Ambiente interno e externo ao desenvolvimento de inovações e também ao Desempenho Organizacional contribuindo para aplicação de novos estudos. Com isso, é possível inferir que existe uma influência favorável da cultura organizacional sobre o ambiente de desenvolvimento de inovações e desempenho organizacional na organização pesquisada.

Palavras-chave: Cultura organizacional; Inovação; Desempenho organizacional.

\section{Introduction}

The textile and clothing market is one of the most dynamic, delivering new launches at least every four months. Brazil ranks fourth among the world's largest producers of clothing and fifth among the largest producers of textiles (ABIT, 2013). For years, Brazilian industry has enjoyed protectionist barriers to preserve the national textile product. However, since the 1990s due to the process of commercial opening, the Brazilian textile industry has had a strong impact against the international competition within its own market (Rangel et al., 2010; Gomes \& Wojahn, 2017).

Although Brazil is a major producer and consumer of textile and clothing products, its share in world trade is less $0.5 \%$, ranking $23 \mathrm{rd}$ in the international trade ranking (ABIT, 2013). Because of this scenario, Brazil's textile industrial park faces strong competition from the international scene for several years, having to undergo significant transformations in its organizational structure, forms of organization of production and labor, technological innovation, among others (Silva \& Queiroz, 2010). In contrast, Brazil has been forming strategic alliances with Asian partners with the purpose of joining forces for survival in competitive price market (ABIT, 2013).

Therefore, the process of innovation has become an inherent and fundamental aspect for the textile industry (Costa \& Rocha, 2009; Monteiro \& Veiga, 2009). It Industry has been oriented by fashion's model, which becomes an effective instrument to increase competitiveness, allows product differentiation (Gimeno, 2000), which resides in the idea of continuous change, with a short product life cycle, brought about by new trends and collections, depending on the efficient diffusion process of innovations (Rech, 2006).

On this environment, which undergoes many changes, has profoundly affected the way organizations position themselves in front of competitive markets, requiring organizations to search for product, process and management innovation. Therefore, organizations that do not have the culture focused on the development of innovations, tend to fail (Machado et al., 2012). In order for innovation to take place, it is necessary that the whole organization is engaged in it, the engine that generates the movements of change, but in order to engage people, an environment that encourages creativity is needed (Ahmed, 1998a).

According this expectation to create an environment conducive to innovation, organizations seek to develop a process of change to influence their leaders in order to try to create an institutional environment of creativity and innovation that will be accepted as basic norms of organizational culture (Martins \& Terblanche, 2003). Culture is capable of stimulating innovative behavior among the members of an 
organization, as it can lead them to accept innovation as a basic value and promote commitment to it (Hartmann, 2006; Naranjo-Valencia, et al., 2016).

Innovating represents the renewal process in any organization. Since a new product can be an important element in the formula for business success, organizations that want to succeed in the competitive environment need innovation at all points, in all aspects of the business and all members of the team. Building an environment fully engaged in positive change and a rich culture of creativity and renewal means creating an organization with 360 degrees of innovation (Kelley \& Littman, 2007).

Innovation supports organizations facing external turbulence and therefore becomes a key player in driving business success (Baker \& Sinkula, 2002). An organization that wants to improve innovation and its organizational performance should pay attention to its organizational culture, since it can be a key enabler of both or a great barrier, depending on the values that make up the current organizational culture of the company (Naranjo-Valencia et al., 2016; Anning-Dorson, 2017; Shahzad et al., 2017) point to a positive and significant relationship between organizational culture and innovation and company performance.

In this sense, this study seeks to validate the relationship between the organizational culture, the innovation environment and the organizational performance. Therefore, the study will employ the model proposed and already studied by Bates et al. (1995), which uses the dimensions of Individualism versus Collectivism, Distance of Power and Cultural Congruence to integrate Organizational Culture and to correlate it with the model proposed by Machado \& Carvalho (2013), which suggests the connection between two dimensions that represent the environment of innovation, being the internal and external dimensions of innovation groups. As a theoretical contribution, the study also seeks to understand the relationship between the organizational culture and the proposed organizational performance of Pérez López et al. (2004) and Jiménez-Jiménez \& Sanz-Valle (2011) who studied the influence of culture on organizational performance, enriching the model proposed by Bates et al. (1995) and Machado \& Carvalho (2013). Given the presented, the research question is: What is the influence of the organizational culture on the internal and external environment of innovation and on the organizational performance in an organization of the textile sector of Santa Catarina?

As theoretical justification, the study aims to verify the relationship between the organizational culture and the environment conducive to the development of innovation, observing the internal and external dimensions of environments conducive to the development of innovation. In addition, the organizational model is added to the model, expanding the model already studied by authors such as van de Ven et al. (2000), Bates et al. (1995), Machado et al. (2010), Jiménez-Jiménez \& Sanz-Valle (2011), Machado \& Carvalho (2013). Despite the importance given to organizational culture as a stimulant for innovation and organizational performance, empirical research on the subject is limited (Naranjo-Valencia et al., 2016). Thus, the study seeks to contribute to the theme that needs to be revised and deepened.

The practical justification stems from the importance of conducting studies in the textile sector, since it has sought to innovate to stay in the market against the Asian competitors. Therefore, it was considered relevant to carry out a research about the influence of the organizational culture on the internal and external environments of innovation and also the influence of the organizational culture on the performance of an organization of the textile sector, and thus to understand about these issues for support in improving the performance of industry organizations. 
The present research is descriptive and causal about the objectives. The approach is presented as quantitative and the procedure for data collection was performed through an intersectional survey. The research was carried out in a traditional organization of the textile sector. The sample consisted of 186 respondents. For the analysis of the data was used the Structural Equations Modeling.

\section{Organizational culture}

Organizational behavior is created at the beginning of organizational life's by means of symbols, languages, beliefs, visions, ideologies and myths; in one effect, this founder and administrator in turn transfers his culture to the organization, assuming a primary responsibility to mobilize people and other resources to the importance of building and administering a new organization (Pettigrew, 1979).

Entrepreneurs can also be seen as creators of some of the more rational and tangible aspects of organizations, such as structures, technologies, and aspects of the more cultural and expressive components of organizational life. The employee, once within this organization, is confronted with an emerging culture through language, performance and observation of daily activities, the regular contact of the people around him and group rituals (Pettigrew, 1979). Thereby, organizational culture is defined as the values of organization, relationships and hierarchy, grounding the behavior patterns and attitudes that define the main actions and decisions of the organization.

In the academy, it was from the 1980s that organizational culture studies gained ground (Pettigrew, 1979; Hofstede, 1980; Ouchi, 1980; Peters et al. 1982; Schein, 1984; between Eastern and Western organizations. This fact was given to research efforts to understand the difference between Eastern and Western reflections on organizational performance, mainly because of the Japanese's ability to overpower American power in automobile production in the 1980s (Ouchi \& Wilkins, 1985).

Schein $(1984,2010)$ conceptualized organizational culture as a standard of basic requirements that the group has invented, discovered or developed in learning to deal with problems of external adaptation and internal integration and which has worked sufficiently well to be considered valid. Therefore, it can be taught to its members as the correct way, as a reflection of the personality of the organization and in a way analogous to the personality of an individual that allows predicting attitudes and behaviors (Bowditch \& Buono, 1997). Therefore, organizational culture refers to values and beliefs that provide standards and expected behaviors that employees could follow (Schein, 1992).

Hofstede (1983) have emphasized the importance of national cultures in shaping organizational cultures. This author defines culture as a collective mental programming that people in an environment have in common. His perception considers the existence of a cultural dependency in which organization and management in organizations do not effectively depend on what to do to achieve tangible goals, but rather on manipulating symbols associated with family, educational systems, politics, religion, and architecture.

Within this context of national cultures, it is possible to observe the Brazilian's culture behavior, in which the organizational culture cannot be considered homogeneous. There is no one Brazil, but many, and in the organizational field it is valid to say that to enhance organizational resources and results organizations that 
recognize cultural codes increase the possibility of gaining local cultural legitimacy (Muzzio, 2010; Gomes, 2013).

Bates et al. (1995), to better describe the difference of these cultures, affirm there are the same three dimensions (typologies) already indicated by Ouchi \& Wilkins (1985), however, distinguished them from the hierarchically- to the organizational clan. Firstly, the individualism versus collectivism that hierarchical culture is guided by the premise of defining, controlling, and evolving through individual contribution generating transformation in processes. Already by the culture of the clan emphasizes the contribution of the group that collectively transforms the processes. Then the distance from power, on it hierarchical cultures emphasize the distance between superiors and subordinates based on formal authority, attained symbolic prestige, and the higher requirements instruct subordinates and their activities by auditing their rules.

Thereby, the role of organizational culture is crucial for the development of innovation (Turró et al., 2013). When an organizational culture is encouraged by innovation capacity, it tolerates risk and supports personal growth and development, and can be labeled as a culture of innovation (Martín-De Castro et al., 2013). Actually, organizations often present more differences in practices than shared basic values. The appropriate way to analyze organizational culture is therefore to focus on the organization's perceptions of the organization's work practices (Galli, 2011; Gomes, 2013).

\subsection{Innovation}

Innovation can be seen as an effective means of enhancing organizational performance (Rajapathirana \& Hui, 2017). Innovation is positively related to the company's performance (Calantone et al., 2002). In the relationship between innovation and organizational performance, Simpson et al. (2006) point out that innovation can be an expensive and risky activity, which can have positive results in solid performance, but also negative results, such as increased exposure to market risk, increased costs and employee dissatisfaction with unexpected consequences in the organization.

The understanding of innovation is related to the generation of ideas, which need to be unprecedented so that they are considered evolutionary and in turn generate processes or products improved for the people through the organizations. It can also generate goods or services that, over time, will revert to results for the organization, making it more competitive (Schumpeter, 1964).

It was from the work of Schumpeter (1964) that a relationship between innovation and economic development was established. In his approach, the capitalist economy is sustained by a constant revolution, called creative destruction. Taking this construction to the organizations, it can be affirm that new technologies and new products replace the old ones. In this sense, innovation produces new things or the same things differently, combining new materials and forces for the purpose of financial return (Schumpeter, 1964).

A creative invention does not become an innovation until it is implemented or institutionalized. In fact, by most standards, the success of an innovation is largely defined in terms of the degree to which financial returns are earned. So, a key measure of innovation is success in the financial return of the idea and a central question is how and why do some new ideas make money while the majority do not? (van de Ven, 1986). 
In Literature the meaning of innovation arises from the implantation of an idea to the creation of a product or service. In the organizational environment, innovation is characterized by the idea of restructuring, cost savings, better communication, deployment of new technology, structures and human resources plans or programs (Martins \& Terblanche, 2003). The generation of positive results from new knowledge and the ability to add more value to society is the definition of innovation presented by Zawislak (2008). This author adds that the impact of innovation ensures the effect of the company being noticed amid resources and assets.

According to Rogers (2001), individuals initially perceive innovation with a high degree of uncertainty and want to know how it works, what degree of risk they can get, and what the advantages and disadvantages are. The author mentions that uncertainties are overcome as one obtains technical information, subjective impressions, and social support about the new idea.

Referring to the innovation process, Barrett \& Sexton (2006) mention two lines of thought: rational and behavioral. Rational thinking describes the process of innovation as something composed of several linear stages. This line of studies described by the authors is criticized for not considering the interactions and the process of movement and feedback of knowledge and resources of the dynamic environment. The behavioral line considers the ambiguities and uncertainties of organizational reality.

Moreover, Barrett \& Sexton (2006) present two aspects to the context of innovation: the vision of market-based innovation and the resource-based view. The market-based view argues that market conditions foster a context that facilitates or constrains innovative activities. The resource-based view, however, considers that market orientation does not allow a safe analysis due to its dynamics and volatility, suggesting that the company's own resources represent a more stable context for the development of the innovation activity.

\subsection{Relationship between organizational culture, innovation and organizational performance}

An organization that wants to improve innovation and performance must pay attention to its organizational culture, since it can be a key enabler of both or a great barrier against both, depending on the values that make up the current organizational culture of the company (Naranjo-Valencia et al., 2016). Quinn \& McGrath (1985) argue that organizational culture influences the culture of innovation that is formed by characteristics that use values of flexibility and adaptation as a means of reaching goals aimed at growth, change and interaction with the external environment, while culture formed by characteristics that involve the hierarchy, uses information management and communications with the goal of maintaining stability and control.

Other previous studies have studied the relationship between organizational culture, innovations and organizational performance. Wright et al. (2005) concluded that product innovation does not affect performance in benign environments (in which the company dominates the market) but has a positive effect on performance in hostile environments (high market competition and competitive environment). The results of Pérez López et al. (2004) demonstrated that innovation contributes positively to the competitiveness of companies and brings financial results. Focusing on a sample of US business service companies, Mansury \& Love (2008) concluded that the presence of innovation has a positive effect on the organization's growth, but no effect on productivity. 
Thereby, culture is at the center of the development of innovation, and the basic elements such as shared values, beliefs, behaviors, influence the development of innovation. This influence can occur in two ways: through the process of socialization in which individuals learn acceptable behaviors and activities. And when values, assumptions and beliefs are established as behaviors and influence management structure, policies and practices (Tushman \& O'Reilly, 1997).

Martins \& Terblanche (2003) analyzed the importance of innovation and creativity in corporate culture, indicating that in organizations, based on knowledge, the success and survival of these depend on creativity and innovation, discovery and originality. The effect is that organizations foster the creation of an institutional environment in which creativity and innovation are accepted as cultural norms in changing environments, emphasizing the importance of organizational culture in this context.

Organizational innovation and learning are affected by organizational values, beliefs, work environment, knowledge sharing and all created by organizational culture (Shahzad et al., 2017). Organizational culture is necessary to foster the sharing of knowledge and creative minds, which are fundamental to organizational success (Shahzad et al., 2017). The perception of employees about the extent to which creativity is encouraged in the workplace and the extent to which organizational resources are allocated to support creativity is likely to influence their innovative behavior. (Gumusluoğlu \& Ilsev, 2009).

In line with this, when they realize that their organization is open to change and supports creative ideas and that there is an adequate supply of resources such as time, people, and funding, they are more likely to perceive the organizational climate as a supporter of innovation and therefore, take risks and promote innovation. (Gumusluoğlu \& Ilsev, 2009). In this sense, the following hypotheses arise: $\mathrm{H} 1$ : The Organizational Culture has a positive influence on the Internal dimension of the innovation group. $\mathrm{H} 2$ : Organizational Culture has a positive influence on the External dimension of the innovation group.

The relationship between organizational culture and performance has been an important topic discussed in the literature. (Schneider et al., 2003; Prajogo \& McDermott, 2011). Researchers and observers acknowledge that organizational culture has an effect on the long-term performance and effectiveness of organizations (Valmohammadi \& Roshanzamir, 2015). Studies have been devoted to examining the role of culture as an organizational resource that affects performance (Prajogo \& McDermott, 2011).

Still, in the relation of Organizational Culture to organizational performance, Lunenburg (2011) emphasizes that the same has an effect according to the behavior of the employees realizing the following points: a) the knowledge of the culture of the organization allows the employees to understand the history and methods of operation; b) organizational culture fosters commitment to the organization's philosophy and values; c) organizational culture, through its norms, serves as a control mechanism to channel behaviors to the desired direction and length of unwanted behaviors; d) certain types of organizational cultures may be directly related to greater effectiveness and productivity (performance).

For Gregory et al. (2009), the fact that culture influences the effectiveness of the firm is an implicit assumption of many managers, yet acknowledge that few empirical studies have provided a detailed view of these relationships. The same authors conclude that, through the analysis of 99 health units in the United States, the 
employee's attitude have a mediating role in the relationship between Organizational Culture and various measures of organizational effectiveness (performance).

The organizational culture that encourages calculated risk-taking and autonomy serves as a precursor to the successful implementation of the innovation strategy. Companies with a strong innovative culture can differentiate themselves in the marketplace and increase their performance by introducing innovations into product and processes (Anning-Dorson, 2017). Thereby, empirical evidence suggests that organizational culture influences market-oriented behaviors and financial performance (Homburg \& Pflesser, 2000), and employee attitudes and organizational effectiveness (Gregory et al., 2009). knowledge management and organizational effectiveness than organizational structure and strategy (Zheng et al., 2010).

Barney (1986), Homburg \& Pflesser (2000) and Hogan \& Coote (2014) discuss the results of organizational culture and performance as a theoretical orientation. Denison \& Mishra (1995) found significant relationships between organizational culture and performance, in which the results demonstrate how different dimensions of culture (eg, participation and mission orientation) can improve different aspects of performance (eg profitability and growth sales). Thus, performance results are associated with organizational culture with greater membership participation through employee engagement with financial performance goals (Denison \& Mishra, 1995). In this sense, the following hypotheses arise: H3: The Organizational Culture has a positive influence on Organizational Performance.

\section{Methodology}

The present research fits as descriptive and causal about the objectives. The approach is presented as quantitative and the procedure for data collection was performed by means of an intersectional survey. According to Babbie (1999), the intersectional survey has as main characteristic the data collection, of a given population, in a single time interval. For Babbie $(1999,78)$, this type of research is characterized by being logical, deterministic, general, parsimonious and because it "typically examines a sample of the population" through the application of a structured questionnaire.

According to Hair Junior et al. (2005), quantitative research is an empirical research whose purpose is to delineate or analyze phenomena, evaluate programs or isolate key variables. This research describes the situations, using quantitative criteria that establish proportions and correlations among observed variables, looking for elements that allow the verification of hypotheses. Still, according to the authors the plans of the descriptive research are formed in order to measure the characteristics of a certain theoretical construct.

The research construct is composed of three parts. The first refers to innovation environments. The model used was the one proposed by Machado \& Carvalho (2013). This model was based on the Minnesota Innovation Survey (MIS) methodology, described by van de Ven et al. (2000), which is part of the Minnesota Innovation Research Program (MIRP) of the University of Minnesota, for analysis of the innovation environment.

The methodology of the Minnesota Innovation Survey (MIS) was tested in its original form in Brazil by Machado (2004), and Carvalho (2010). The work of Machado \& Carvalho (2013) analyzed the theoretical constructs and observed the possibility of grouping the dimensions, which through factorial analysis proved feasible due to the 
multicollinearity between the data. Thereby, the 29 dimensions proposed by van de Ven at al. (2000) were reduced to 10, which included internal dimensions, external dimensions and results, so that one impact on the other. Each group of dimensions is composed of sub-dimensions, as presented in Table 1, with the authors that formed them the theoretical construct.

Table 1. Dimensions of the innovation environment.

\begin{tabular}{ccccc}
\hline Groups & \multicolumn{2}{c}{ Dimensions } & Actors \\
\cline { 2 - 3 } & D1 & Results & Kimberly (1981), van de Ven (1986).
\end{tabular}

Source: Machado \& Carvalho (2013, p. 598).

The second part of the environment model conducive to the development of innovations, added to the model proposed by Machado et al. (2010), which deals with the theme "innovation environments" the variable "organizational culture", used for this purpose the questionnaire adapted from Bates et al. (1995). The authors Bates et al. (1995), through a research conducted and validated in 41 manufacturing companies, verified a relationship between organizational culture and production strategy. As this study focuses on innovation, questions regarding manufacturing strategies have been removed. The three dimensions of organizational culture remained unchanged, being (1) individualism versus collectivism, (2) distance from power, and (3) cultural congruence.

The data collection instrument of Bates et al. (1995) was used in other works, such as Machado et al. (2009), Kanungo et al. (2001), Balthazard \& Cooke (2004), Balthazard et al. (2006), Koufteros et al. (2007), Moran \& Meso (2008), Naor et al. (2010) and Machado et al. (2010, 2012). 
From this perspective, Scarpin (2012) reduced the questionnaire from 35 to 17 questions. For this, a test was performed with the pre-existing database of Machado et al. (2010), of the original model. For reduction, we used data considering each of the scales belonging to the dimensions proposed by the authors and the tangency that they could have among themselves. After this procedure, the factorial analysis was carried out in order to verify which constant issues in each of the phases were correlated with each other and being more representative, had greater commonalities.

Identifying the issues that best represented each of the phases described, the means of the answers were made with the objective of reaching a single measure of that phase. In continuity, the frequencies of the means of the phases and the dimensions, before and after the reduction of the data, were compared by means of the Chi-square test. Churchill Junior (1979) and Stratman \& Roth (2002) argue that this methodology validates the reduction of data in the evaluation of constructs (Scarpin, 2012).

Finally, the last part regarding organizational performance was studied by researchers such as Coombs \& Hull (1998), Hall \& Andriani (2003), Pérez López et al. (2004), Chiva et al. (2007), García-Morales et al. (2007), Zheng et al. (2010), JiménezJiménez \& Sanz-Valle (2011), Gunday et al. (2011), Bolívar-Ramos et al. (2012) and Camisón \& Villar-López (2014).

According this line, this research seeks to understand the influence of organizational culture on the internal and external environment of innovation and on organizational performance (Figure 1). The organizational performance will be analyzed according to the model of Pérez López et al. (2004) and Jiménez-Jiménez \& Sanz-Valle (2011), observing the economic and financial results dimension, with four questions to evaluate results, analyzing a minimum scenario of 3 years, according to the employees of the company studied.

The data of the present research were primary and collected by the researchers, through a research collection instrument composed of a questionnaire. The data collection instrument is composed of five blocks. The first one contains the questions of descriptive variables that evaluate characteristics of the respondents, such as: gender, age, workspace, education, position and company time. The second block seeks to understand the internal dimensions of the innovation group, such as: results, processes, resources, leadership, autonomy, internal relationship and external relationship. The third block seeks to understand the external dimensions of the innovation group, addressing dependence on external resources, formalization and effectiveness of the relationship.

The fourth block evaluates aspects of organizational culture such as: Individualism Versus Collectivism, distance of power and cultural congruence. The 7-point Likert scale was used, ranging from 1 (strongly disagree) to 7 (I totally agree). The fifth block raises aspects of organizational performance such as customer loyalty, sales growth, profitability and return on investment. In this, the Likert scale was used, with scores varying from 1 to 7 , with 1 representing (Much worse than competitors) and 7 (Much better than competitors).

The social subjects were selected for convenience, covering all sectors, that is, from the administrative sector to the production sector of the surveyed company that has 900 employees in the researched branch. The accessibility sample obtained degree of significance and sample error calculated based on Barbetta (2012). The sample for this 
research was calculated with sampling error of $5 \%$, degree of significance $95 \%$, resulting in 270 respondents of a sample.

As a rule, Lomax \& Schumacker (2004) agree that a sample of 100 to 150 cases is the minimum size for Structural Equations Modeling - SEM. Hair Junior et al. (2009) suggest a sample size of 200 cases. Regarding the proportion of cases, the minimum is to have at least five times more observations than the number of variables to be analyzed, and the most appropriate size would be ten to one. With this, the minimum proportion is five respondents for each estimated variable, ten being the most adequate. The model proposed in this study has 44 variables. Thus, the suggested sample would be 205 respondents.

Therefore, 462 questionnaires were distributed, and 289 returned, of which 103 had to be discarded because of the quality of the response, in which respondents left more than 20 blank answers, totaling a final valid sample of 186 respondents for analysis, being next to the sample suggested by the literature (Hair Junior et al., 2009). In Table 2, the dimensions of organizational culture, performance, and the respective authors are based on each one.

Table 2. Dimensions of organizational culture and organizational performance.

\begin{tabular}{llll}
\hline \multicolumn{1}{c}{ Group } & \multicolumn{1}{c}{ Dimension } & \multicolumn{1}{c}{ Actors } \\
\hline $\begin{array}{l}\text { Organizational D11 } \\
\text { Culture }\end{array}$ & $\begin{array}{l}\text { Individualism versus } \\
\text { Collectivism }\end{array}$ & Ouchi (1980), Taylor \& Bowers (1972) \\
\cline { 2 - 4 } & D12 & Power Distance & Ouchi (1980), Aiken \& Hage (1966) \\
\cline { 2 - 4 } D13 & Cultural Congruence & $\begin{array}{l}\text { Deal \& Kennedy (1982), Mowday et al. } \\
\text { (1981), Price \& Mueller (1986) }\end{array}$ \\
\hline $\begin{array}{l}\text { Organizational D14 } \\
\text { Performance }\end{array}$ & $\begin{array}{l}\text { Customer loyalty } \\
\text { Sales Growth } \\
\text { Profitability } \\
\text { ROI - Return of } \\
\text { Investment }\end{array}$ & $\begin{array}{l}\text { Coombs \& Hull (1998), Hall \& Andriani } \\
\text { (2003), Pérez López et al. (2004), } \\
\text { Chiva et al. (2007) and Jiménez-Jiménez \& } \\
\text { Sanz-Valle (2011) }\end{array}$ \\
\hline
\end{tabular}

Source: Self elaboration.

The organizational culture on this process supports the emergence of an environment conducive to innovation. The analysis model will have as predictive variable the organizational culture, here represented by the study of Bates et al. (1995), indicating values that implicitly impel individuals to innovate (Machado et al., 2012). Finally, to evaluate the influence of the organizational culture on the internal and external environment of innovation and on the organizational performance. The conceptual basis suggests the model according to Figure 1. 


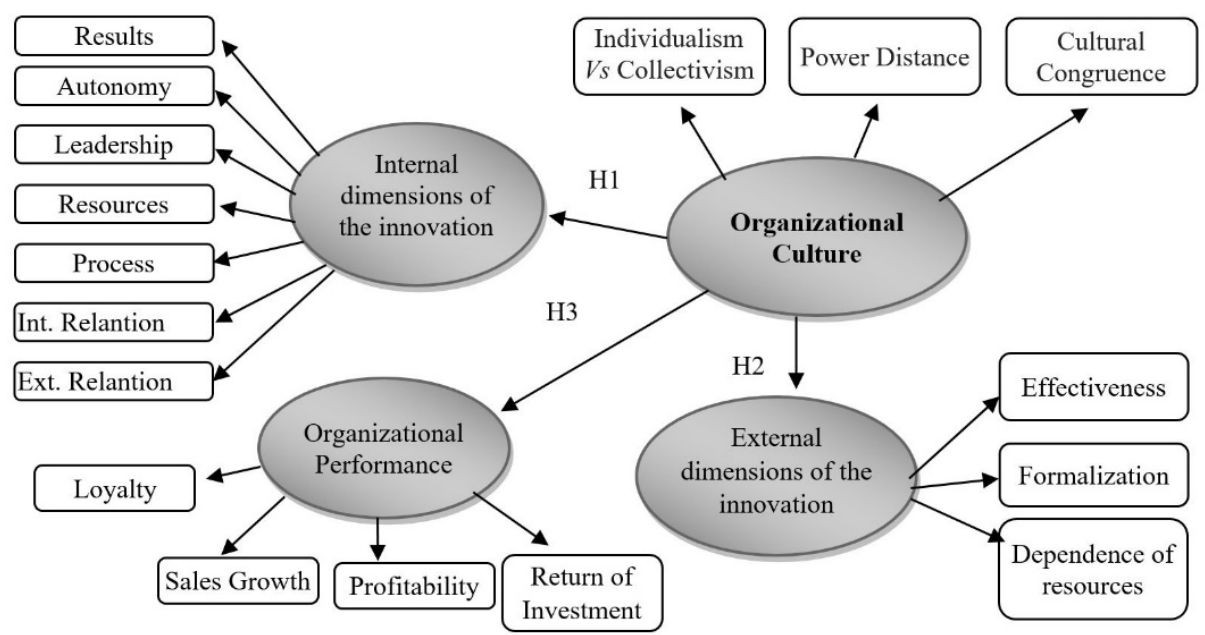

Figure 1. Model encompasses culture, innovation and organizational performance. Source: Self elaboration.

The model as presented in Figure 1 proposes as the first and second hypothesis that organizational culture has influence on internal and external dimensions to the development of an environment conducive to innovation and as a last hypothesis that organizational culture also influences organizational performance.

For the analysis of the data was used the Structural Equations Modeling - SEM. Choice by this method is appropriate when the purpose of the study lies between the need to test a theory and to predict patterns. The SEM does not refer to a technique, but rather to a set of statistical procedures, which on certain occasions is cited in the literature as analysis of the covariance structure or modeling of the covariance structure (Kline, 2005).

\subsection{Data processing and analysis}

Firstly, the missing data was identified, which occurs when the respondent fails to inform one or more questions of the data collection instrument, in this case 103 questionnaires had to be discarded because they had more than 20 blank responses, other 9 questionnaires had less than 5 blank responses and were replaced by the average responses. This definition suggests that there are levels of unavailability of information and then seeks a level of misconduct from which distortions of results would be unacceptable. The influence of data lost in the research is the reduction of the sample size available for the analysis (Hair Junior et al., 2009).

Then, the reliability of each construct was evaluated separately. Cronbach's Alpha was used for this purpose. For Malhotra (2006) values above 0.6 are considered acceptable. Thereby, for this study, the cut-off index used was 0.6 . If any dimension does not present sufficient reliability was used to verify the reliability after the excluded variable, although as a requirement, the number of variables resulting from the dimension must be at least three variables, since it is the minimum for the reliability calculation via SPSS Software 23.

After that the composite reliability and extracted variance analysis were used. According to the literature, it is accepted as reasonable values from 0.60 (Skerlavaj \& Dimovski, 2009) for composite reliability and mean variance extracted (MVE) which 
should have a value of at least 0.45 (Netemeyer et al., 2003). At this point also if there is not enough reliability variables are excluded in order to evaluate if they remain with sufficient significance and can be used in the model.

In order to validate the integrated model, the individual validation of the constructs or submodels was carried out by means of the Confirmatory Factor Analysis (CFA), in order to verify the validity of the constructs involved in the measurement model. The use of CFA in the structural equations modeling allows the evaluation of the reliability and validity of the constructs (Garver \& Mentzer, 1999). The CFA will involve the analysis of the adjustment indices and the convergent validity analysis. The overall adjustment measures of the model are divided into three categories: absolute adjustment measures, incremental adjustment measures, and parsimonious adjustment measures.

According to Hair Junior et al. (2005) is required an evaluation of the measures, since no measure emerged as singular for model assessment. After this procedure was performed the Structural Equations Modeling - SEM. The SEM seeks to explain the relationships among multiple variables by examining the structure of interrelationships expressed in a series of equations, similar to those of multiple regression (Hair Junior et al., 2009). For this procedure the statistical software used was SPSS AMOS 21.0, which allows to generate the equations of correlation between the dimensions, graphically demonstrating the impact value and the values for the explanation of the model $\left(R^{2}\right)$, thus waiting to be evaluated the influence of the culture organizational approach to the enabling environment for innovation and organizational performance.

As a conclusion of the reliability analysis, in the first instance, Cronbach's Alpha $(\mathrm{CA}>=0.6)$, Composite Reliability $(\mathrm{CR}>=0.6)$ and Average Variance Extracted (AVE > = 0.45 ) above acceptable it is necessary to purify the dimensions: 1-Result, 9-Formalization, 10-Effectiveness in Relationship, 11-Individualism vs. Collectivism, 13-Congruence, 14Performance, all apt to be considered in the structural equations modeling.

However, there were dimensions that needed to be purified, but did not have the minimum number of variables that allowed the use of the technique, such as: 4-Leadership, 5-Autonomy, 6-Internal relationship to the innovation group, 7-External relationship to the innovation group and 8-External Resources Unit. These, in turn, were discarded the use in the structural equations modeling for having low reliability within a minimum of three variables per dimension.

Table 3 presents the final result after purification of the possible dimensions, such as: 2-Processes, 3-Resources and 12-Distance of the Power being considered in the structural equations model, however, the dimension 3-Resources after purification also had to be discarded because it presents low reliability and there is no possibility of re-exclusion due to the minimum number of variables.

Table 3. Reliability by Dimension after purification.

\begin{tabular}{|c|c|c|c|c|c|c|}
\hline Dimension & $\begin{array}{c}\text { Original } \\
\text { Model } \\
\text { Variables }\end{array}$ & $\begin{array}{c}\text { Variables } \\
\text { after } \\
\text { Purification }\end{array}$ & $\frac{(\mathrm{CA})}{>0.6}$ & $\begin{array}{r}(\mathrm{CR}) \\
>0.6\end{array}$ & $\begin{array}{c}\text { (AVE) } \\
>0.45\end{array}$ & $\begin{array}{c}\text { Does } \\
\text { reliability } \\
\text { needed } \\
\text { for SEM? }\end{array}$ \\
\hline \multicolumn{7}{|c|}{ Internal Innovation Group } \\
\hline 1-Results & 3 & 3 & 0.7 & 0.72 & 0.48 & Yes \\
\hline 2-Process & 4 & 3 & 0.69 & 0.68 & 0.45 & Yes \\
\hline 3-Resources & 4 & 3 & 0.67 & 0.67 & 0.4 & No \\
\hline 4-Leadership & 3 & 3 & 0.56 & 0.61 & 0.36 & No \\
\hline
\end{tabular}


Table 3. Continued...

\begin{tabular}{|c|c|c|c|c|c|c|}
\hline Dimension & $\begin{array}{c}\text { Original } \\
\text { Model } \\
\text { Variables }\end{array}$ & $\begin{array}{c}\text { Variables } \\
\text { after } \\
\text { Purification }\end{array}$ & $\frac{(\mathrm{CA})}{>0.6}$ & $\begin{array}{r}(\mathrm{CR}) \\
>0.6\end{array}$ & $\begin{array}{c}\text { (AVE) } \\
>0.45\end{array}$ & $\begin{array}{l}\text { Does } \\
\text { reliability } \\
\text { needed } \\
\text { for SEM? }\end{array}$ \\
\hline \multicolumn{7}{|c|}{ External Innovation Group } \\
\hline $\begin{array}{c}\text { 8-Dependence of External } \\
\text { Resources }\end{array}$ & 3 & 3 & 0.5 & 0.54 & 0.31 & No \\
\hline 9-Formalization & 3 & 3 & 0.78 & 0.79 & 0.56 & Yes \\
\hline 10-Effectiveness in Relationship & 3 & 3 & 0.74 & 0.77 & 0.54 & Yes \\
\hline \multicolumn{7}{|c|}{ Organizational Culture } \\
\hline 11-Individualism vs. Collectivism & 8 & 8 & 0.9 & 0.89 & 0.52 & Yes \\
\hline 12-Power Distance & 4 & 3 & 0.72 & 0.73 & 0.48 & Yes \\
\hline 13-Congruence & 5 & 5 & 0.86 & 0.87 & 0.64 & Yes \\
\hline \multicolumn{7}{|c|}{ Organizational Perfomance } \\
\hline 14-Performance & 4 & 4 & 0.85 & 0.85 & 0.59 & Yes \\
\hline
\end{tabular}

Source: Self elaboration. Cronbach's Alpha - CA. Composite Reliability - CR. Average Variance Extracted - AVE. Structural Equations Modeling - SEM.

\section{Data analysis and discussion}

This stage aims to answer the hypotheses raised in the study that deal with the influence of organizational culture on the internal and external environment dimensions of innovation groups and organizational performance in a company in the textile industry. For this, the SEM was used, firstly, through the adjustment indices (for the purpose of verifying whether the model is acceptable or not) and, finally, validity (to evaluate if the items reflect the construct). Table 4 shows the adjustment indices of the proposed final model.

With regard to the adjustment of the model, the $X 2$ / GL presented an index of 2.229, the adjustment quality index (GFI) was lower than 0.9 , as well as the Adjusted Quality of Adjustment Index (AGFI). However, it should be noted that Bagozzi \& Yi (1988) emphasize that there are no cut-off criteria for GFI and AGFI; these indices are dependent on the sample size.

The Standardized Root Mean-Square Residual $(S R M R=0.151)$ did not meet the recommended criteria, being slightly higher than 0.10 , however the Root Mean Square Error of Approximation (RMSEA $=0.08$ ) met the recommended criterion, be equal to 0.08. The Tuker-Lewis index (TLI) was close to the expected level, with a value of 0.810. The same was true of the comparative adjustment index (CFI), which had a value of 0.826 , that is, near the desirable value of 0.9 . The other indexes were also within the range recommended by the literature.

It is worth noting that no similar studies were found in the literature, which on the one hand allows this to be a pioneering study in the subject, but on the other hand, it harms the discussion of the results found. Considering the novelty of analysis of the proposed theoretical model and the absence of antecedent empirical evidences that allow effective comparisons, it is understood that the model, although it has not demonstrated satisfactory values in all the adjustment measures, can be improved with new empirical studies, therefore, not invalidating it. After checking the adjustment of the model, the standardized factor loads and the respective t-values were analyzed in order to test the hypotheses, as the Table 4. 
Table 4. Standardized coefficients and test of the hypotheses of the relations of the proposed model.

\begin{tabular}{ccccccccc}
\hline \multicolumn{2}{c}{ Structural Pathways } & Estimate & S.E & t- Values & P-Value & Coef \\
\hline \multicolumn{2}{c}{ Dimensions of Organizational Culture } & & & \\
\hline $\begin{array}{c}\text { Individualism Vs } \\
\text { Coletivism }\end{array}$ & $<==$ & $\begin{array}{c}\text { Organizational } \\
\text { Culture }\end{array}$ & $1.00(1)$ & - & - & - & 0.82 \\
\hline Power Distance & $<==$ & $\begin{array}{c}\text { Organizational } \\
\text { Culture }\end{array}$ & 1.347 & 0.19 & 7.225 & $*$ & 0.97 \\
\hline Congruence & $<==$ & $\begin{array}{c}\text { Organizational } \\
\text { Culture }\end{array}$ & 1.078 & 0.13 & 8.362 & $* * *$ & 0.83 \\
\hline Internal Innovation & $<==(\mathrm{H} 1)$ & $\begin{array}{c}\text { Organizational } \\
\text { Culture }\end{array}$ & $1.00(1)$ & - & - & $* * *$ & 0.64 \\
\hline External Innovation & $\begin{array}{c}<== \\
(\mathrm{H} 2)\end{array}$ & $\begin{array}{c}\text { Organizational } \\
\text { Culture }\end{array}$ & 0.709 & 0.16 & 4.453 & $* * *$ & 0.64 \\
\hline $\begin{array}{c}\text { Organizational } \\
\text { Performance }\end{array}$ & $\begin{array}{c}<== \\
(\mathrm{H} 3)\end{array}$ & $\begin{array}{c}\text { Organizational } \\
\text { Culture }\end{array}$ & 0.513 & 0.1 & 4.918 & $* * *$ & 0.46 \\
\hline
\end{tabular}

Source: Self elaboration. (1) Initial values set at 1.00. ${ }^{* *} p<0,001$. S.E $=$ Standard Error.

In terms of indicators for accepting hypotheses, t-values need to be greater than 1.96 (for tolerable acceptance); the recommended is above 2.58, to accept appropriate significance (Hair Junior et al., 2005). According to Table 4, the results were satisfactory, that is, the three hypotheses raised in the literature were confirmed.

Figure 2 shows a dimensionality representation of the Culture of Innovation construct after purification. As a way to obtain an acceptable level of fit for the study, the proposed dimensions for the model were simulated: Organizational Culture, Internal Dimensions of Innovation, External Dimensions of Innovation and Organizational Performance. In standardized factor loads, the indicators should be statistically significant, with standardized loads above or close to 0.60 , since the objective in this phase is to purify the measurement scale.

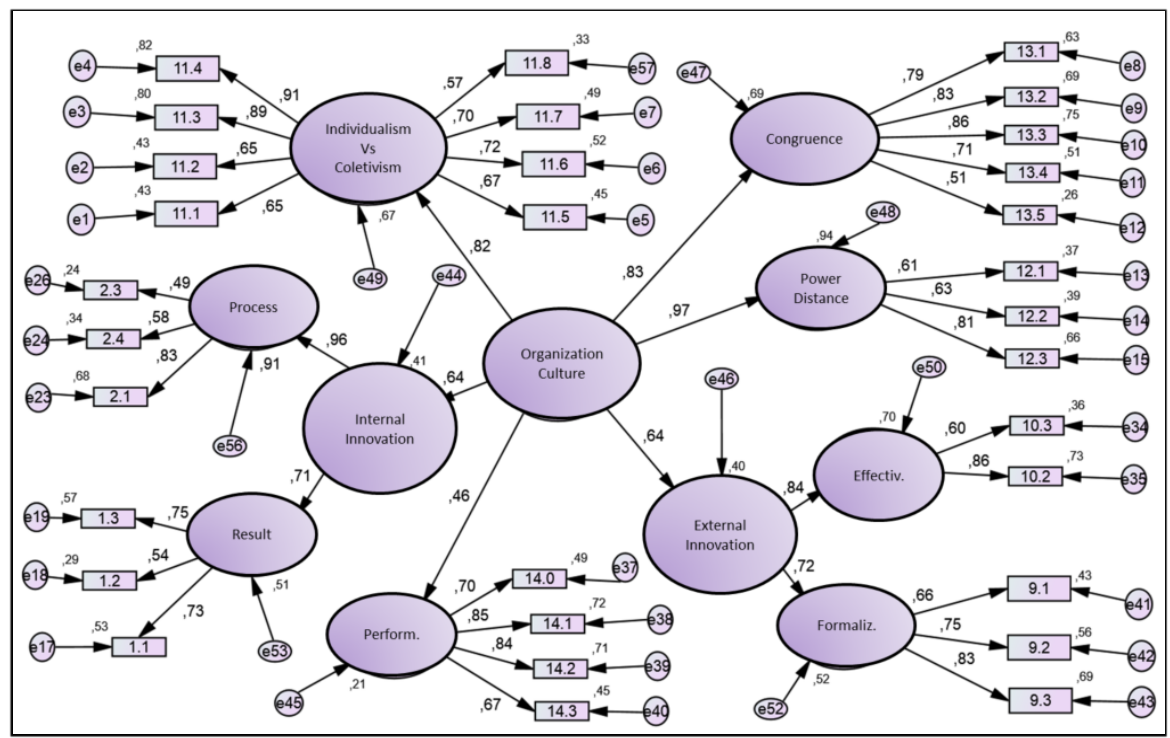

Figure 2. Relationship of Organizational Culture and the internal and external dimensions of the innovation and organizational performance group.. Source: Self elaboration. 
Analyzing Figure 2, it can be seen that the Endogenous Internal Environment Dimension construct of the Innovation Group is represented in order of greatest impact by the dimensions Process in (0.96) and Result (0.71). Thereby, the influence of the Organizational Culture construct on the Internal Dimensions of the Innovation Group is (0.64). For Schein $(1984,2010)$, organizational culture happens through experiences, experiences and achievements, which over time have become the right way to do things.

Therefore, the organization studied has a strong cultural congruence, focused on collectivism and a smaller distance from power (Bates et al., 1995). According that the exogenous Organizational Culture construct positively impacts (0.64) on the endogenous Construct Internal Dimensions of the Innovation group.

These results corroborate those found by the following authors: Scarpin (2012) who tested the hypothesis in a metalworking company, which resulted in a load of (0.55), with the most impacted internal dimensions being Leadership (0.66), Process $(0.61)$ and Internal relation (0.56). Then Torres (2014) tested in a software development company, which resulted in a load of $(0.435)$, however there were more impacted dimensions such as Leadership (0.67), Internal Relationship (0.73), Process (0.80), Autonomy (0.82) and Resources (0.77). Finally, Depiné \& Machado (2015) evaluated in a multinational company, which resulted in a load of $(0.94)$, and the internal dimensions most impacted were Internal Relations (0.84), Leadership (0.71), Processes (0.50) and Resources (0.40).

Thereby, it is possible to infer from the results that there is a concordance with previous studies about the influence of organizational Culture on the internal environments of innovation, however, each organization emphasizes in a particular way the set of internal dimensions that are impacted by the culture of according to the cultural moment lived by the organization. For Gumusluoğlu \& Ilsev (2009) organizations can internally support innovation by encouraging, recognizing and rewarding creativity as well as providing adequate amounts of resources such as staff, funding and time.

In addition, it is possible to observe that the exogenous external environment construct of the innovation group is composed of the Formalization and Effectiveness dimensions of the Relationship, which explain the construct with coefficients of $(0.72)$ and (0.84), respectively. Organizational Culture influences (0.64) the External Dimensions of the Innovation group. Thus, affirming that there is a positive impact of the exogenous construct Organizational Culture on the endogenous construct Dimensions External to the Innovation group.

Through a congruent culture that seeks to minimize the distance from power and promote collectivism (Bates et al., 1995), the organization surveyed shows that the collaborators realize that the partnerships established with other teams for the development of the idea are important and worth (van de Ven et al., 2000; Machado \& Carvalho, 2011).

These results corroborate with the same authors who had already evaluated the internal innovations. Scarpin (2012) with a load of (0.47), with the most impacted external dimensions being Relationship Effectiveness - Partnership (0.73), Effectiveness in Relationship - Commitment (0.49) and Internal Relationship - Adaptability (0.28). Then Torres (2014) with a load of (0.383), and impacted dimensions were Resource Dependence (0.87), Formalization (0.86) and Effectiveness in Relationships (0.83). Finally, Depiné \& Machado (2015) with a load of $(0.81)$ and the most affected internal dimensions were Effectiveness - Satisfaction (0.81), Formalization (0.64) and Effectiveness - Conflicts (0.60). 
Therefore, it is possible to infer through the results that the influence of the Organizational Culture on the external environments of innovation occurs. However, each organization also highlights in a particular way the set of external dimensions that are impacted by the culture according to the cultural moment lived by the organization. For Shahzad et al. (2017) organizational culture can significantly stimulate creativity and innovative behavior among employees. Due to the nature of innovation, formal rules and regulations can be kept to a minimum and provide an open climate to allow creative ideas to flourish.

And finally, the exogenous Organizational Performance construct is composed of the affirmations Loyalty of the clients; Sales growth; Profitability of the company and Return on investment, which explain the construct with coefficients of $(0.70),(0.85)$, $(0.84)$ and $(0.67)$, respectively. Organizational culture influences $(0.46)$ organizational performance. In this way, it is possible to affirm that there is a positive influence of the exogenous Organizational Culture construct on the endogenous Organizational Performance construct.

Sackmann (2011) argue that organizational performance is the result of the different types of culture and intensity of cultural strength presented by the company. Thus, culture can have positive consequences on individual and organizational performance (Naor et al., 2014; Broadbent \& Laughlin, 2009).

Previous studies such as that of Pérez López et al. (2004), García-Morales et al. (2007) and Jiménez-Jiménez \& Sanz-Valle (2011) were carried out to measure the influence of organizational learning culture and innovation on organizational performance using the structural equation method and both showed positive influence. Other studies such as de Gunday et al (2011) presented load (0.53), Bolívar-Ramos et al. (2012) with load (0.19) and Camisón \& Villar-López (2014) with load (0.23) also had a positive influence of organizational culture focused on innovation on organizational performance.

Still Rosenbusch et al. (2011) found a positive relationship in the organizational culture dimension, moderating the influence of innovation on organizational performance. Finally, the study Zheng et al. (2010) presented a positive relationship between the organizational culture, through values, norms and artifacts, about organizational efficiency as financial performance goals. According to Shahzad et al. (2017), organizational and innovation performance depends on the innovative skills of an organization and the internal and external interaction of employees (Shahzad et al., 2017).

Organizations are social and physical constructs and therefore an understanding of organizational culture can help shape the process of innovation and organizational performance. (Hogan \& Coote, 2014). In this sense, it is necessary for the organization to develop an innovation-oriented culture model that can effectively manage constant change.

The results of this study indicate that there is a favorable influence of organizational culture on organizational performance. Managers must recognize and manage culture to increase organizational performance. However, it is recommended to develop other descriptive studies like this, in other sectors of the economy, for the model to be proven.

\section{Findings and limitations}

The organizations seek to perpetuate themselves through the generations by structuring corporate governance in favor of an organizational culture that is committed to meeting the challenges posed by the global economic scenario, seeking a 
technological and management model that results in superior organizational performance.

An aspect that is part of this context and has been for decades as a competitive differential supporting the performance of organizations, is the innovative model employed by organizations, which portrays how the organizational culture maintains the internal and external environments of innovation. So, when an organization seeks to shape its organizational culture in favor of creativity and innovation, in essence, it seeks to influence its employees in search of a ritual that makes the organization more efficient, that is, with greater performance.

Therefore, this research sought to identify how the organizational culture, being measured as an independent variable can influence the internal and external environments of innovation, as well as, the organizational performance in an organization of the textile sector. The research has shown, according the results, that an organization with a Clan culture positively impacts the perception of the environment of development of innovations. The results of the present study corroborate the hypothesis of previous studies by Machado (2004), Machado et al. (2012), Machado \& Carvalho (2013), Scarpin (2012), Depiné \& Machado (2015), Neumann (2013) and Torres (2014) related to the impact of organizational culture and own environments to the development of innovations.

In addition, the influence of organizational culture dimensions on organizational performance was verified. The study demonstrated that organizational culture positively impacts organizational performance. As well as, the study showed that the proposed model with the inclusion of dimensions related to organizational culture and performance are adherent to the model already studied.

Previous studies have argued that innovation has positively affected performance in hostile, difficult-to-market, competitive environments in which the ability to innovate will respond more quickly to the challenges posed (Wright et al., 2005; Brown \& Eisenhardt, 1995). Therefore, developing an organizational culture that looks at innovative issues is critical to performance in hard times.

Thereby, it is possible to affirm that the innovations are fruit of ideas, that are implanted with success, once the organization has a propitious environment for the development of internal and external innovations. However, for this it is fundamental that the company seeks to develop its current organizational culture by stimulating an environment conducive to innovations. As well, engage your employees in seeking understanding about the current performance of the organization, fostering a collaborative environment between the emergence of the idea and the transformation into tangible results.

As a scientific contribution, this study seeks to support researchers who study the relationship between organizational culture, innovation and organizational performance, within a quantitative approach. The result of the proposed model, besides confirming in a more economic environment the positive relationship between organizational culture and innovation environments, has brought a new approach that is the positive relationship between organizational culture and organizational performance. Obviously, it is suggested that these results be replicated in future studies.

On the other hand, the contribution of this work to the textile sector was to try to understand the relationship of organizational culture and performance through the adoption of an innovative process, culminating in the development of new organizational strategies from these reflections for the sector. In organizations in this 
industry, a culture of innovation is a crucial precursor to the development of innovative behaviors that can sustain organizations and promote organizational performance. Organizations are social and physical constructs, and, in this sense, an understanding of organizational culture can help shape the innovation process and consequently the company's performance.

As a limitation of this research it is possible to cite the cross-section and the application of this research to a single object of study and limited number of respondents. Also, the fact that the research sample is not probabilistic and with only 186 respondents. Certainly, a more representative and representative sample of the population would allow a greater validity of the results. It may be mentioned as a limitation that the use of a self-filled questionnaire implies in the respondent's bias regarding the information reported. Another bias refers to the understanding of the items of the questionnaire, and it is natural that the respondents present dubious understanding regarding certain assertions of the questionnaire.

The biases of the researcher's own interpretation are also cited as a limitation of the research. As for the methodological limitations, one can consider the quantitative approach used for research on organizational culture, since authors defend the qualitative approach. As a recommendation, we highlight the application of this model in other textile organizations in order to establish possible comparisons. As well as test the influence in other studies of the application of the organizational culture dimension on the organizational performance dimension.

\section{References}

Ahmed, P. K. (1998a). Benchmarking innovation best practice. Benchmarking for Quality Management \& Technology, 5(1), 45-58. http://dx.doi.org/10.1108/14635779810206803.

Aiken, M., \& Hage, J. (1966). Organizational alienation: a comparative analysis. American Sociological Review, 31(4), 497-507. http://dx.doi.org/10.2307/2090773.

Anning-Dorson, T. (2017).Moderation-mediation effect of market demand and organization culture on innovation and performance relationship. Marketing Intelligence \& Planning, 35(2), 222-242. http://dx.doi.org/10.1108/MIP-04-2016-0066.

Associação Brasileira da Indústria Têxtil e de Confecção - ABIT. (2013). Indústria têxtil e de confecção brasileira. São Paulo: ABIT. Retrieved in 2016, May 30, from http://www.abit.org.br/conteudo/links/publicacoes/cartilha_rtcc.pdf

Babbie, E. (1999). Métodos de pesquisas de survey (Tradução Guilherme Cezarino). Belo Horizonte: Ed. UFMG.

Bagozzi, R. P., \& Yi, Y. (1988). On the evaluation of structural equation models. Journal of the Academy of Marketing Science, 16(1), 74-94. https://doi.org/10.1007/BF02723327.

Baker, W. E., \& Sinkula, J. M. (2002). Market orientation, learning orientation and product innovation: delving into the organization's black box. Journal of Market Focused Management, 5(1), 5-23. http://dx.doi.org/10.1023/A:1012543911149.

Balthazard, P. A., \& Cooke, R. A. (2004). Organizational culture and knowledge management success: assessing the behavior-performance continuum. In Anais do 37th Hawaii International Conference on System Sciences (pp. 1-10). Big Island, HI: HICSS. http://dx.doi.org/10.1109/HICSS.2004.1265577.

Balthazard, P. A., Cooke, R. A., \& Potter, R. E. (2006). Dysfunctional culture, dysfunctional organization: capturing the behavioral norms that form organizational culture and drive performance. Journal of Managerial Psychology, 21(8), 709-732. http://dx.doi.org/10.1108/02683940610713253. 
Barbetta, P. A. (2012). Estatística aplicada às ciências sociais. Florianópolis: Ed. UFSC

Barney, J. B. (1986). Organizational culture: can it be a source of sustained competitive advantage? Academy of Management Review, 11(3), 656-665. http://dx.doi.org/10.5465/amr.1986.4306261.

Barrett, P., \& Sexton, M. (2006). Innovation in small. Project-Based Construction Firms, 17(4), 331-346. http://dx.doi.org/10.1111/j.1467-8551.2005.00461.x.

Bates, K. A., Amundson, S. D., Schroeder, R. G., \& Morris, W. T. (1995). The crucial interrelationship between manufacturing strategy and organizational culture. Management Science, 41(10), 1565-1580. http://dx.doi.org/10.1287/mnsc.41.10.1565.

Blake, R. R., \& Mouton, J. (1964). The managerial grid. Houston, Texas: Gulf.

Bolívar-Ramos, M. T., García-Morales, V. J., \& García-Sánchez, E. (2012). Technological distinctive competencies and organizational learning: effects on organizational innovation to improve firm performance. Journal of Engineering and Technology Management, 29(3), 331-357. http://dx.doi.org/10.1016/j.jengtecman.2012.03.006.

Bowditch, J. L., \& Buono, A. F. (1997). Elementos de comportamento organizacional. São Paulo: Pioneira.

Broadbent, J., \& Laughlin, R. (2009). Performance management systems: a conceptual model. Management Accounting Research, 20(4), 283-295. http://dx.doi.org/10.1016/j.mar.2009.07.004.

Brown, S. L., \& Eisenhardt, K. M. (1995). Product development: past research, present findings, and future directions. Academy of Management Review, 20(2), 343-378. http://dx.doi.org/10.5465/amr.1995.9507312922.

Burke, R. J. (1970). Method of resolving superior-subordinate conflict: the constructive use of subordinate differences and disagreements. Organizational Behavior and Human Performance, 5(4), 393-411. http://dx.doi.org/10.1016/0030-5073(70)90029-2.

Calantone, R. J., Cavusgil, S. T., \& Zhao, Y. (2002). Learning orientation, firm innovation capability, and firm performance. Industrial Marketing Management, 31(6), 515-524. http://dx.doi.org/10.1016/S0019-8501(01)00203-6.

Camisón, C., \& Villar-López, A. (2014). Organizational innovation as an enabler of technological innovation capabilities and firm performance. Journal of Business Research, 67(1), 28912902. http://dx.doi.org/10.1016/j.jbusres.2012.06.004.

Carvalho, L. C. (2010). Ambiente de inovação: análise multidimensional em uma organização do setor metal-mecânico (Dissertação de mestrado). Fundação Universidade Regional de Blumenau, Blumenau.

Chiva, R., Alegre, J., \& Lapiedra, R. (2007). Measuring organizational learning capability among the workforce. International Journal of Manpower, 28(3), 224-242. http://dx.doi.org/10.1108/01437720710755227.

Churchill Junior, G. A. (1979). A paradigm for developing better measures of marketing constructs. JMR, Journal of Marketing Research, 16(1), 64-73. http://dx.doi.org/10.1177/002224377901600110.

Coombs, R., \& Hull, R. (1998). Knowledge management practices and path-dependency in innovation. Research Policy, 27(3), 237-253. http://dx.doi.org/10.1016/S00487333(98)00036-5.

Costa, A. C. R., \& Rocha, E. R. P. (2009). Panorama da cadeia produtiva têxtil e de confecções e a questão da inovação (pp. 159-202). Rio de Janeiro: BNDES Setorial.

Deal, T. E., \& Kennedy, A. A. (1982). Corporate cultures: the rites and rituals of corporate life. Massachusetts: Adisson-Wesley.

Denison, D. R., \& Mishra, A. K. (1995). Toward a theory of organisational culture and effectiveness. Organization Science, 6(2), 204-223. http://dx.doi.org/10.1287/orsc.6.2.204. 
Depiné, M., \& Machado, D. D. P. N. (2015). Ambiente favorável ao desenvolvimento de inovações: a cultura pode exercer Influência? Revista do ICSA - Gestão e Desenvolvimento, 12(1), 33-49. Retrieved in 2016, June 5, from http://periodicos.feevale.br/seer/index.php/revistagestaoedesenvolvimento/article/download $146 / 46$

Galli, E. B. (2011). Building social capital in a multibusiness firm: lessons from a case study. Wiesbaden: Gabler. http://dx.doi.org/10.1007/978-3-8349-6171-6.

García-Morales, V. J., Lloréns-Montes, F. J., \& Verdú-Jover, A. J. (2007). Influence of personal mastery on organizational performance through organizational learning and innovation in large firms and SMEs. Technovation, 27(9), 547-568. http://dx.doi.org/10.1016/j.technovation.2007.02.013.

Garver, M. S., \& Mentzer, J. T. (1999). Logistics research methods: employing structural equation modeling to test for construct validity. Journal of Business Logistics, 20(1), 33-57. Retrieved in 2016, June 5, from https://search.proquest.com/openview/a778d630df6747e2918f1527a34cbd76/1?pqorigsite $=$ gscholar $\& \mathrm{cbl}=36584$

Gimeno, J. M. I. (2000). La gestión del diseño en la empresa. Madrid, España: McGrawHill/Interamericana de España.

Gomes, G. (2013). Cultura de inovação e sua influência no desempenho em inovação de produtos na indústria têxtil de Santa Catarina (Tese de doutorado). Programa de Pósgraduação em Ciências Contábeis, Universidade Regional de Blumenau, Blumenau.

Gomes, G., \& Wojahn, R. M. (2017). Organizational learning capability, innovation and performance: study in small and medium-sized enterprises (SMES). Revista de Administração (São Paulo), 52(2), 163-175. http://dx.doi.org/10.1016/j.rausp.2016.12.003.

Gregory, B. T., Harris, S. G., Armenakis, A. A., \& Shook, C. L. (2009). Organizational culture and effectiveness: a study of values, attitudes, and organizational outcomes. Journal of Business Research, 62(7), 673-679. http://dx.doi.org/10.1016/j.jbusres.2008.05.021.

Gross, N., Giacquinta, J., \& Bernstein, M. (1971). Implementation organizational innovations. New York: Basic Books.

Gumusluoğlu, L., \& Ilsev, A. (2009). Transformational leadership and organizational innovation: the roles of internal and external support for innovation. Journal of Product Innovation Management, 26(3), 264-277. http://dx.doi.org/10.1111/j.1540-5885.2009.00657.x.

Gunday, G., Ulusoy, G., Kilic, K., \& Alpkan, L. (2011). Effects of innovation types on firm performance. International Journal of Production Economics, 133(2), 662-676. http://dx.doi.org/10.1016/j.ijpe.2011.05.014.

Hackman, J. R., \& Oldham, G. R. (1975). Development of the job diagnostic survey. The Journal of Applied Psychology, 60(2), 159-170. http://dx.doi.org/10.1037/h0076546.

Hair Junior, J. F., Anderson, R. E., Tatham, R. L., \& Black, W. C. (2009). Análise multivariada de dados (A. S. Sant'Ana e A. C. Neto, Trad.). Porto Alegre: Bookman.

Hair Junior, J. F., Babin, B., Money, A. H., \& Samouel, P. (2005). Fundamentos de métodos de pesquisa em administração. Porto Alegre: Bookman.

Hall, R., \& Andriani, P. (2003). Managing knowledge associated with innovation. Journal of Business Research, 56(2), 145-152. http://dx.doi.org/10.1016/S0148-2963(01)00287-9.

Hartmann, A. (2006). The role of organizational culture in motivating innovative behaviour in construction firms. Construction Innovation, 6(3), 159-172. http://dx.doi.org/10.1108/14714170610710712.

Hofstede, G. (1980). Culture's consequences: international differences in work-related values. Beverly Hills: Sage. 
Hofstede, G. (1983). The cultural relativity of organizational practices and theories. Journal of International Business Studies, 14(2), 75-89.

http://dx.doi.org/10.1057/palgrave.jibs.8490867.

Hogan, S. J., \& Coote, L. V. (2014). Organizational culture, innovation, and performance: a test of Schein's model. Journal of Business Research, 67(8), 1609-1621. http://dx.doi.org/10.1016/j.jbusres.2013.09.007.

Homburg, C., \& Pflesser, C. (2000). A multiple-layer model of market-oriented organizational culture: measurement issues and performance outcomes. JMR, Journal of Marketing Research, 37(4), 449-462. http://dx.doi.org/10.1509/jmkr.37.4.449.18786.

Jiménez-Jiménez, D., \& Sanz-Valle, R. (2011). Innovation, organizational learning, and performance. Journal of Business Research, 64(4), 408-417. http://dx.doi.org/10.1016/j.jbusres.2010.09.010.

Kantner, R. M. (1983). The change masters. New York: Simon and Schuster.

Kanungo, S., Sadavarti, S., \& Srinivas, Y. (2001). Relating it strategy and organizational culture: an empirical study of public sector units in India. The Journal of Strategic Information Systems, 10(1), 29-57. http://dx.doi.org/10.1016/S0963-8687(01)00038-5.

Kelley, T., \& Littman, J. (2007). As 10 faces da inovação: estratégias para turbinas a criatividade (Tradução de Afonso Celso da Cunha Serra). Rio de Janeiro: Elsevier.

Kimberly, J. (1981). Managerial innovation. In P. \& Nystrom \& W. Starbuck (Org.), Handbook of organizational design (pp. 84-104). Oxford: Oxford University Press.

Kline, R. B. (2005). Principles and practice of structural equation modeling. New York: The Guilford Press.

Koufteros, X. A., Nahm, A. Y., Cheng, T. C. E., \& Lai, K. H. (2007). An empirical assessment of a nomological network of organizational design constructs: from culture to structure to pull production to performance. International Journal of Production Economics, 106(2), 468492. http://dx.doi.org/10.1016/j.ijpe.2006.08.001.

Lawrence, P. R., \& Lorsch, J. W. (1967). Differentiation and integration in complex organizations. Administrative Science Quarterly, 12(1), 1-47. http://dx.doi.org/10.2307/2391211.

Lawrence, P., \& Dyer, P. (1983). Renewing american industry. New York: Free Press.

Lomax, R. G., \& Schumacker, R. E. (2004). A beginner's guide to structural equation modeling. England: Psychology Press.

Lunenburg, F. C. (2011). Organizational culture-performance relationships: views of excellence and theory Z. National Forum of Education Administration and Supervision Journal, 29(4), 52-63. Retrieved in 2016, June 5, from https://pt.scribd.com/document/110650300/Organization-Culture-PerformanceRelationships-Views-of-Excellence-and-Theory-Z-by-Dr-Fred-C-Lunenburg-Published-inthe-NATIONAL-FORUM-OF-EDUCAT

Machado, D. D. P. N. (2004). Inovação e cultura organizacional: um estudo dos elementos culturais que fazem parte de um ambiente inovador (Tese de doutorado). Escola de Administração de Empresas de São Paulo, Fundação Getúlio Vargas, São Paulo.

Machado, D. D. P. N., \& Carvalho, C. (2013). E. Ambiente favorável ao desenvolvimento de inovações: proposição de um modelo de análise organizacional. Revista ADM, 48(3), 592607. http://dx.doi.org/10.5700/rausp1108.

Machado, D. D. P. N., \& Carvalho, C. E. (2011). Ambiente favorável ao desenvolvimento de inovações: proposição de um modelo de análise organizacional. In Anais do XXXV Encontro da ANPAD. Rio de Janeiro: Editora da ANPAD.

Machado, D. D. P. N., Carvalho, L. C., \& Heinzmann, L. M. (2010). Ambiente Favorável ao desenvolvimento de inovações: integração de duas perspectivas de análise. In Anais do 
XXVI Simpósio de gestão da Inovação Tecnológica da ANPAD (SGIT). (pp. 1-17). Rio de Janeiro: Editora da ANPAD.

Machado, D. D. P. N., Carvalho, L. C., \& Heinzmann, L. M. (2012). Ambiente favorável ao desenvolvimento de inovações e cultura organizacional: integração de duas perspectivas de análise. Revista de Administração, 47(4), 715-729. http://dx.doi.org/10.5700/rausp1069.

Machado, D. D. P. N., Heinzmann, L. M., \& Loesch, C. (2009). Estratégia de produção e cultura organizacional: podem estar inter-relacionadas? In Anais do XIII Seminário Latinoiberoamericano de Gestión Tecnológica. Cartagena, Colômbia: ALTEC.

Malhotra, N. K. (2006). Pesquisa de marketing: uma orientação aplicada (4. ed.). Porto Alegre: Artmed.

Mansury, M. A., \& Love, J. H. (2008). Innovation, productivity and growth in US business services: a firm-level analysis. Technovation, 28(1-2), 52-62. http://dx.doi.org/10.1016/j.technovation.2007.06.002.

Martín-De Castro, G., Delgado-Verde, M., Navas-López, J. E., \& Cruz-González, J. (2013). The moderating role of innovation culture in the relationship between knowledge assets and product innovation. Technological Forecasting and Social Change, 80(2), 351-363. http://dx.doi.org/10.1016/j.techfore.2012.08.012.

Martins, E. C., \& Terblanche, F. (2003). Building organisational culture that stimulates creativity and innovation. European Journal of Innovation Management, 6(1), 64-74. http://dx.doi.org/10.1108/14601060310456337.

McGrath, J. E. (1984). Groups: interaction and performance. Englewood Cliff: Prentice-Hall.

Monteiro, P. R. R., \& Veiga, R. T. (2009). Personalidade e segmentação do mercado de moda: contrastes e perfil de jovens inovadores segundo o gênero. Revista Pretexto, 10(1), 69-87. Retrieved in 2016, June 5, from http://www.fumec.br/revistas/pretexto/article/view/479/474

Moran, T. J., \& Meso, P. (2008). A resource based view of manufacturing strategy and implications to organizational culture and human resources. Journal of Business \& Economics Research, 6(11), 99-110. Retrieved in 2016, June 5, from https://www.cluteinstitute.com/ojs/index.php/JBER/article/download/2494/2540

Mowday, R., Steers, R. M., \& Porter, L. W. (1981). The measurement of organizational commitment. Journal of Vocationial Behavior, 14(2), 224-227. http://dx.doi.org/10.1016/0001-8791(79)90072-1.

Muzzio, H. (2010). Cultura organizacional e perspectivas estratégicas da regionalidade cultural brasileira. In Anais Encontro de Estudos Organizacionais (pp. 1-16). Florianópolis: ANPAD.

Naor, M., Jones, J. S., Bernardes, E. S., Goldstein, S. M., \& Schroeder, R. (2014). The cultureeffectiveness link in performance in a manufacturing context: a resource-based perspective. Journal of World Business, 49(3), 321-331. http://dx.doi.org/10.1016/j.jwb.2013.06.003.

Naor, M., Linderman, K., \& Schroeder, R. (2010). The globalization of operations in Eastern and Western countries: unpacking the relationship between national and organizational culture and its impact on manufacturing performance. Journal of Operations Management, 28(3), 194-205. http://dx.doi.org/10.1016/j.jom.2009.11.001.

Naranjo-Valencia, J. C., Jiménez-Jiménez, D., \& Sanz-Valle, R. (2016). Studying the links between organizational culture, innovation, and performance in Spanish companies. Revista Latinoamericana de Psicología, 48(1), 30-41. http://dx.doi.org/10.1016/j.rlp.2015.09.009.

Netemeyer, R. G., Bearden, W. O., \& Sharma, S. (2003). Scaling procedures: issues and applications. Thousand Oaks - CA: Sage. http://dx.doi.org/10.4135/9781412985772.

Neumann, M. (2013). A influência da cultura organizacional sobre o ambiente favorável ao desenvolvimento de inovações: estudo em instituição de corpo de bombeiros voluntários (Dissertação de mestrado). Universidade Regional de Blumenau, Blumenau. 
Ouchi, W. G. (1980). Markets, bureaucracies and clans. Administrative Science Quarterly, 25(1), 129-141. http://dx.doi.org/10.2307/2392231.

Ouchi, W. G., \& Wilkins, A. L. (1985). Organizational culture. Annual Review of Sociology, 11(1), 457-483. http://dx.doi.org/10.1146/annurev.so.11.080185.002325.

Pérez López, S., Manuel Montes Peón, J., \& José Vázquez Ordás, C. (2004). Managing knowledge: the link between culture and organizational learning. Journal of Knowledge Management, 8(6), 93-104. http://dx.doi.org/10.1108/13673270410567657.

Perrow, C. B. (1967). A framework for the comparative analysis of organizations. American Sociological Review, 32(2), 194-208. Retrieved in 2016, June 5, from http://www.jstor.org/stable/2091811

Peters, T. J., Waterman, R. H., \& Jones, I. (1982). In search of excellence: lessons from America's best-run companies. New York: Harper \& Row.

Pettigrew, A. M. (1979). On studying organizational cultures. Administrative Science Quarterly, 24(4), 570-581. http://dx.doi.org/10.2307/2392363.

Prajogo, D. I., \& McDermott, C. M. (2011). The relationship between multidimensional organizational culture and performance. International Journal of Operations \& Production Management, 31(7), 712-735. http://dx.doi.org/10.1108/01443571111144823.

Pressman, S., \& Wildavsky, H. (1973). Implementation. Berkerly: University of California Press.

Price, J. L., \& Mueller, C. H. (1986). Handbook of organizational measurement. Marshfield: Pitman.

Quinn, R. E., \& McGrath, M. R. H. (1985). The Transformation of organizational cultures: a competing values perspective. In: P. J. Frost, L. F. Moore, M. R. Louis, C. C. Lundberg, \& J. Martin (Eds.). Organizational culture. Newvury Park: Sage.

Rajapathirana, R. P. J., \& Hui, Y. (2017). Relationship between innovation capability, innovation type, and firm performance. Journal of Innovation \& Knowledge, 3(1), 44-55. http://dx.doi.org/10.1016/j.jik.2017.06.002.

Rangel, A. S., Silva, M. M., \& Costa, B. K. (2010). Competitividade da indústria têxtil brasileira. Revista de Administração e Inovação, 7(1), 151-174. http://dx.doi.org/10.5585/rai.v7i1.367.

Rech, S. R. (2006). Cadeia produtiva da moda: um modelo conceitual de análise da competitividade no elo confecção (Tese de doutorado). Universidade Federal de Santa Catarina, Florianópolis.

Rogers, E. M. (2001). Evolution: diffusion of innovations (pp. 4982-4986). USA: International Encyclopedia of the Social \& Behavioral Sciences.

Rosenbusch, N., Brinckmann, J., \& Bausch, A. (2011). Is innovation always beneficial? A metaanalysis of the relationship between innovation and performance in SMEs. Journal of Business Venturing, 26(4), 441-457. http://dx.doi.org/10.1016/j.jbusvent.2009.12.002.

Sackmann, S. A. (2011). Culture and performance. In Ashkanasy et al (Eds.), The handbook of organizational culture and climate (2nd ed., pp 188-224). Thousand Oaks: Sage. http://dx.doi.org/10.4135/9781483307961.n12.

Scarpin, M. R. S. (2012). O impacto da cultura sobre ambiente propício ao desenvolvimento de inovações. (Dissertação de mestrado). Universidade Regional de Blumenau, Blumenau.

Schein, E. H. (1984). Coming to a new awareness of organizational culture. Sloan Management Review, 25(2), 3-16. Retrieved in 2016, June 5, from http://www.sietmanagement.fr/wpcontent/uploads/2016/04/culture_schein.pdf

Schein, E. H. (1992). Organizational culture and leadership. San Francisco: Jossey-Bass Inc.

Schein, E. H. (2010). Organizational culture and leadership. John Wiley \& Sons.

Schneider, B., Hanges, P. J., Smith, B., \& Salvaggio, A. N. (2003). Which comes first: employee attitudes or organizational financial and market performance? The Journal of Applied 
Psychology, 88(5), 836-851. http://dx.doi.org/10.1037/0021-9010.88.5.836. PMid:14516248.

Schumpeter, J. A. (1964). Teoria do desenvolvimento econômico. Rio de Janeiro: Círculo do Livro.

Shahzad, F., Xiu, G. Y., \& Shahbaz, M. (2017). Organizational culture and innovation performance in Pakistan's software industry. Technology in Society, 51, 66-73. http://dx.doi.org/10.1016/j.techsoc.2017.08.002.

Shull, F. A., Delbecq, A. L., \& Cummings, L. L. (1970). Organizational decision making. New York: McGraw-Hill.

Silva, F. L. A., \& Queiroz, S. N. (2010). Indústria têxtil: avaliação empírica do emprego formal em Santa Catarina vis-à-vis o Ceará - 1998/2008. In Anais do IV Encontro de Economia Catarinense. Criciúma: UNESC.

Simpson, P. M., Siguaw, J. A., \& Enz, C. A. (2006). Innovation orientation outcomes: the good and the bad. Journal of Business Research, 59(10), 1133-1141. http://dx.doi.org/10.1016/j.jbusres.2006.08.001.

Skerlavaj, M., \& Dimovski, V. (2009). Organizational learning and performance in two national cultures: a multi-group structural equation modeling approach. Knowledge management and organizational learning (pp. 321-366). Nova lorque: Springer.

Stratman, J. K., \& Roth, A. V. (2002). Enterprise Resource Planning (ERP) competence constructs: two-stage Multi-item scale development and validation. Decision Sciences, 3(4), 601-628. http://dx.doi.org/10.1111/j.1540-5915.2002.tb01658.x.

Taylor, J. C., \& Bowers, D. B. (1972). Survey of organizations: a machine scored standardized questionnaire instrument. Ann Arbor, MI: Institute for Social Research, University of Michigan.

Torres, A. S. (2014). O impacto da cultura sobre ambiente propício ao desenvolvimento de inovações em uma empresa de tecnologia de informação (Dissertação de mestrado). Universidade Regional de Blumenau, Blumenau.

Turró, A., Urbano, D., \& Peris-Ortiz, M. (2013). Culture and innovation: the moderating effect of cultural values on corporate entrepreneurship. Technological Forecasting and Social Change, 88, 360-369. http://dx.doi.org/10.1016/j.techfore.2013.10.004.

Tushman, M. L., \& O'Reilly, C. A. (1997). Winning through innovation: a practical guide to leading organizational change and renewal. Boston: Harvard Business School Press. http://dx.doi.org/10.1108/eb054591.

Valmohammadi, C., \& Roshanzamir, S. (2015). The guidelines of improvement: relations among organizational culture, TQM and performance. International Journal of Production Economics, 164, 167-178. http://dx.doi.org/10.1016/j.jpe.2014.12.028.

van de Ven, A. H. (1976). On the nature, formation and maintenance of interorganizational relationships. Academy of Management Review, 1(4), 24-36. http://dx.doi.org/10.5465/amr.1976.4396447.

van de Ven, A. H. (1980). Problem solving, planning, and innovation. Part I. Test of the program planning model. Human Relations, 33(10), 711-740. http://dx.doi.org/10.1177/001872678003301003.

van de Ven, A. H. (1986). Central problems in the management of innovation. Management Science, 32(5), 590-607. http://dx.doi.org/10.1287/mnsc.32.5.590.

van de Ven, A. H., Angle, H. L., \& Poole, M. S. (Eds.). (2000). Research on the management of innovation: The Minnesota studies. New York: Oxford University.

van de Ven, A. H., \& Ferry, D. L. (1980). Measuring and assessing organizations. New York: Wiley.

Wright, R. E., Palmer, J. C., \& Perkins, D. (2005). Types of product innovations and small business performance in hostile and benign environments. Journal of Small Business 
Strategy, 15(2), 33-44. Retrieved in 2018, January 11, from http://libjournals.mtsu.edu/index.php/jsbs/article/view/33

Zawislak, P. A. (2008). Contribuições para uma medida geral de inovação. In Anais da XXXII Encontro da ANPAD (pp. 1-16). Rio de Janeiro: Enanpad.

Zheng, W., Yang, B., \& Mclean, G. N. (2010). Linking organizational culture, structure, strategy, and organizational effectiveness: mediating role of knowledge management. Journal of Business Research, 63(7), 763-771. http://dx.doi.org/10.1016/j.jbusres.2009.06.005. 